Jurnal MAKSIPRENEUR, Vol. I, No. 1, 2011, hal. 1-20

\title{
KOPERASI SUKSES INDONESIA
}

\author{
M. Dawam Rahardjo \\ Universitas Proklamasi 45 (The University of Petroleum), Yogyakarta
}

\begin{abstract}
In June 2011 the PIP (Pusat Informasi Perkoperasian) magazine has been launched in releasing a list of 100 Successful Cooperative Indonesia. It has been following the tradition of the ICA Global 300 which contains a list of the most successful cooperatives from all over the world. We notice that a lot of cooperatives could be successful, however, we also are haunted by the question: "Are the successful cooperatives still have been known as 'identity' Coop?!" Did the cooperative have to abandon his identity in order to scoop up a successful?! This paper attemps to outline the dilemma.
\end{abstract}

Key Words: Cooperative, Cooperative Identity, Economic Democracy

\section{PENDAHULUAN}

Dalam makalah prasarannya, "Perkembangan Koperasi di Indonesia" (1954), yang disampaikan pada Seminar Gabungan Koperasi Batik Indonesia (GKBI), yang merupakan salah satu koperasi sukses di Indonesia pada waktu itu, Dr. Saroso Wirodihardjo-pada waktu itu menjabat Kepala Jawatan Perdagangan dan Kepala Direktorat Perdagangan dan Perindustrian pada Kementerian Perdagangan dan Perindustrian, yang bertanggung jawab mengurusi koperasi sebagai lembaga penggerak perdagangan dan perindustrian seperti pada zaman penjajahanmenguraikan bahwa jika menyimak sejarah perkembangannya, mulai dari masa Boedi Oetomo hingga tahun 1950-an, pada pokoknya perkembangan koperasi bersumber pada tiga institusi atau jalur.

Pertama, koperasi pada mulanya berkembang karena digerakkan oleh organisasi sosial dan politik, seperti Boedi Oetomo, Sarekat Dagang Islam (SDI), Persatuan Bangsa Indonesia (PBI), Partai Indonesia Raya (Parindra), dan kemudian diikuti oleh partai-partai politik lainnya pada masa kemerdekaan. Kedua, digerakkan atau dibantu oleh pemerintah, baik itu pemerintah Hindia Belanda pada masa kolonial, maupun pemerintah Republik Indonesia setelah Proklamasi. Dan ketiga merupakan inisiatif seseorang, kelompok masyarakat, atau dunia usaha, sebagai bagian dari masyarakat sipil (civil society). 


\section{KOPERASI DAN CAMPUR TANGAN PEMERINTAH}

Organisasi kemasyarakatan dan partai politik memang berhasil menggerakkan masyarakat untuk mendirikan koperasi-koperasi secara massal, namun koperasi-koperasi yang lebih didorong oleh semangat dan ideologi politik itu, misalnya menentang kapitalisme dan politik perekonomian pemerintah kolonial, gagal untuk menjadikan koperasi sebagai organisasi usaha yang berhasil secara komersial. Sebabnya adalah karena kurang dan tiadanya perhatian pada aspek keterampilan usaha yang berdasarkan motif ekonomi dan tiadanya pengetahuan mengenai asas-asas koperasi dan pengelolaannya (cooperative governance). Kekurangan ini disadari oleh pemerintah yang kemudian berusaha untuk memberdayakan koperasi melalui undang-undang dan peraturan serta kegiatan pembinaan dan intervensi kebijaksanaan lainnya.

Di masa kemerdekaan, campur tangan pemerintah ini dilakukan secara lebih intensif di masa Ekonomi Terpimpin (1959-1965) yang menempatkan koperasi dalam kerangka ideologi sosialis. Pada waktu itu juga agendaagenda partai politik, seperti PNI, Masyumi, PKI dan NU juga menyusup ke dalam gerakan dan organisasi koperasi, sehingga terjadi politisasi gerakan koperasi. Tapi campur tangan pemerintah itu sudah lebih lunak jika dibandingkan dengan pada masa pendudukan Jepang, yang menggunakan organisasi koperasi sebagai lembaga eksploitasi terhadap rakyat untuk pengadaan pangan dan bahan baku industri, termasuk di dalamnya untuk mobilisasi tenaga kerja, sehingga asas partisipasi dan emansipasi yang melekat pada koperasi menjadi rusak, sesuatu yang sempat menimbulkan krisis kepercayaan masyarakat terhadap koperasi.

Namun demikian, terdapat perbedaan antara pengaruh politik pada masa Hindia Belanda dengan pada masa kemerdekaan. Pada masa penjajahan, politisasi koperasi diarahkan kepada gerakan perlawanan dan penegakkan strategi politik non-kooperasi terhadap pemerintah Hindia Belanda, sedangkan pada masa kemerdekaan politisasi mengarah kepada penggunaan organisasi koperasi untuk kepentingan politik partai. Yang pertama menimbulkan semangat swadaya dan independensi, sedangkan yang kedua mengundang campur tangan pemerintah untuk menjadikan koperasi sebagai bagian dari sistem ekonomi nasional sesuai dengan gagasan konstitusi ekonomi dalam UUD 1945.

Pada masa pemerintahan Orde Baru terjadi proses metamorfosis peranan pemerintah dalam perkembangan koperasi. Pertama, pemerintah melakukan reformasi organisasi koperasi melalui UU dan peraturan. Kedua, pemerintah menjadikan koperasi sebagai alat kebijaksanaan, khususnya untuk mendukung program pembangunan pertanian. Ketiga, pemerintah memberikan bisnis atau bidang usaha kepada koperasi. Keempat, 
pemerintah menyediakan faktor-faktor produksi, seperti kredit, tenaga manajer, bahan baku, dan alat-alat produksi. Kelima, pemerintah melakukan modernisasi organisasi koperasi melalui pendidikan dan informasi. Keenam, pemerintah melakukan pemberdayaan kapasitas (capacity building) kelembagaan koperasi. Ketujuh, pemerintah menciptakan proyek-proyek pembangunan koperasi, misalnya pengembangan KUD (Koperasi Unit Desa) dan kemitraan koperasi dengan BUMN atau perusahaan swasta sebagai bagian dari program pemerintah. Dan kedelapan, pemerintah memberikan hibah, misalnya untuk membangun kantor atau kendaraan.

Intervensi dan peranan pemerintah itu memunculkan preseden, dimana usaha gerakan koperasi kemudian cenderung lebih banyak dilakukan untuk meminta bantuan pemerintah. Hal ini misalnya terjadi pada kalangan gerakan koperasi batik nasional, yaitu GKBI. Sejak berkembangnya industri batik pada awal abad ke-20, para pengusaha batik sangat membutuhkan bahan baku, khususnya mori atau cambrics, yang distribusinya dikuasai atau dimonopoli oleh pedagang Belanda dan keturunan Cina. Pada mulanya GKBI hanya sekedar ingin berhubungan langsung dengan importir saja, tetapi kemudian berjuang untuk mendapatkan lisensi sebagai importir, yang pada akhirnya mereka kemudian ditunjuk sebagai importir tunggal kain mori.

Setelah berhasil menjadi importir tunggal itu maka GKBI menyalurkan bahan baku itu kepada pengusaha yang menjadi anggota koperasi batik primer. Dari situ maka koperasi menciptakan keuntungan pada tiga level. Pertama, di level gabungan koperasi (GKBI). Kedua di level koperasi primer. Dan ketiga di level anggota koperasi yang bisa mendapatkan jatah bahan baku dengan harga murah. Maksud koperasi sebenarnya adalah bahwa bahan baku itu diolah sendiri oleh anggota GKBI. Namun yang terjadi kemudian adalah sebagian bahan baku itu dijual ke pasar sehingga menimbulkan perdagangan di luar koperasi. Melalui praktik itu GKBI bisa menghimpun modal dengan cepat dan mendirikan perusahaan mori sendiri. Demikian juga berbagai koperasi primer, mereka akhirnya mendirikan pabrik sendiri sehingga kemudian terjadi proses industrialisasi. Dalam posisi itu koperasi bertindak sebagai investor industri dan sekaligus sebagai distributor (kepada anggota koperasi primer). Melalui pengalaman GKBI itu, maka lahir persepsi bahwa pemerintah dapat berperan strategis dalam membangun koperasi. Di masa industrialisasi Eropa, investor industri adalah kaum feodal dan pedagang, golongan yang memiliki modal. Sedangkan di Indonesia pada tahun 1950-an, investor industri bahan baku batik adalah koperasi dari hasil perdagangan berdasarkan kebijaksanaan yang memihak, atau pro-koperasi.

Strategi dan kebijaksanaan industrialisasi melalui perkembangan perdagangan internasional untuk membentuk modal nasional adalah 
konsep yang diajukan oleh Sumitro Djojohadikusumo pada waktu ia menjabat Menteri Perdagangan dan Perindustrian dalam Kabinet Natsir (1950-1951). Strategi dan kebijaksanaan itu diterapkan ulang pada masa ia menjabat sebagai Menteri Perdagangan dalam Kabinbet Pembangunan I (1969-1974) di masa pemerintahan Orde Baru, yaitu dengan membentuk sindikat-sindikat importir yang bisa menjadi sumber pembentukan modal dari keuntungan perdagangan impor.

TABEL 1

INDIKATOR SUKSES 7 KUD TERBESAR DARI JUMLAH ANGGOTA, ASET DAN VOLUME USAHA (DALAM JUTA DAN ORANG)

\begin{tabular}{|c|l|c|c|c|c|c|}
\hline No. & \multicolumn{1}{|c|}{ Nama Koperasi } & Jenis Usaha & $\begin{array}{c}\text { Volume } \\
\text { Usaha }\end{array}$ & $\begin{array}{c}\text { VU/A } \\
(\mathbf{x})\end{array}$ & Asset & Anggota \\
\hline 1 & KUD Batu, Jawa Timur & $\begin{array}{c}\text { Susu, Waserda, } \\
\text { Madu dan } \\
\text { Peternakan }\end{array}$ & 102.387 & 6 & 16.919 & 2.061 \\
\hline 2 & $\begin{array}{l}\text { KUD Sumber } \\
\text { Makmur, Jawa Timur }\end{array}$ & $\begin{array}{c}\text { Sapi Perah dan } \\
\text { USP }\end{array}$ & 101.400 & 5 & 20.000 & 6.369 \\
\hline 3 & $\begin{array}{l}\text { KUD Sejahtera, } \\
\text { Sumsel }\end{array}$ & $\begin{array}{c}\text { Angkutan, Kelapa } \\
\text { Sawit, USP dan } \\
\text { Waserda }\end{array}$ & 80.638 & 5 & 17.888 & 1.579 \\
\hline 4 & $\begin{array}{l}\text { KUD Kopta } \\
\text { Samarinda, Kaltim }\end{array}$ & $\begin{array}{c}\text { Pupuk, Pertanian } \\
\text { BBM dan Toko }\end{array}$ & 70.280 & 12 & 5.657 & 984 \\
\hline 5 & $\begin{array}{l}\text { KUD Bantarangin, } \\
\text { Jawa Timur }\end{array}$ & $\begin{array}{c}\text { USP, Foto Copy } \\
\text { dan Toko }\end{array}$ & 58.105 & 4 & 15.842 & 1.224 \\
\hline 6 & $\begin{array}{l}\text { KUD Sumbe Rejo, } \\
\text { Jawa Timur }\end{array}$ & $\begin{array}{c}\text { Pangan, USP dan } \\
\text { Distributor }\end{array}$ & 42.736 & 3 & 12.830 & 9.000 \\
\hline 7 & $\begin{array}{l}\text { KUD Dadi Jaya, Jawa } \\
\text { Timur }\end{array}$ & $\begin{array}{c}\text { Sapi Perah, USP, } \\
\text { Waserda dan } \\
\text { Pakan Ternak }\end{array}$ & 57.800 & 2 & 31.800 & 1.735 \\
\hline
\end{tabular}

Pelajaran inilah yang kemudian ditarik oleh pemerintah Orde Baru. Misalnya pemerintah kemudian menjadikan KUD sebagai penyalur sarana produksi pupuk kepada petani anggotanya. Tetapi karena pemerintah sudah memiliki BUMN yang memproduksi pupuk, maka koperasi dianggap tidak perlu mendirikan pabrik pupuk sendiri. Ini agak berbeda dengan di Amerika Serikat atau Kanada, dimana di sana koperasi diberi kesempatan (atau mengambil kesempatan) untuk mendirikan industri pupuk sendiri, sehingga industri pupuk yang berbasis koperasi bisa berkembang. Demikian pula halnya di India, koperasi pupuk yang memiliki pabrik sendiri berhasil masuk menjadi salah satu koperasi terbesar dalam daftar Global 300 yang dirilis ICA (International Cooperative Alliance). Sebagai agen penyalur pupuk, mestinya semua KUD bisa menjadi unit usaha yang berhasil. Apalagi anggota KUD juga bisa memperoleh kredit dari Bank Rakyat Indonesia (BRI) yang mendapat penugasan dari pemerintah untuk menyalurkan kredit 
usaha tani, tidak saja bagi petani untuk membeli pupuk, tetapi juga KUD bisa mendapatkan kredit guna membeli produk petani anggota untuk kemudian diolah dan dijual kepada Bulog (Badan Urusan Logistik). Gambaran KUD sukses pada tahun 2011 nampak pada Tabel 1.

Model KUD itu diterapkan pada koperasi-koperasi serba usaha yang lain yang kemudian berkembang menjadi semacam "sistem jatah", alias sebagai penyalur bantuan pemerintah. Pada akhirnya koperasi kemudian seolah-olah bekerja sebagai jawatan pemerintah, dimana ia berkecenderungan untuk tidak bekerja sebagai unit usaha yang didorong oleh motif ekonomi dan sekadar organisasi berwatak sosial sebagaimana hakikat sistem koperasi menurut UU No. 12/1967. Akibatnya, koperasi kemudian menjadi lembaga ekonomi yang tidak berkelangsungan, karena ia sangat tergantung kepada pemerintah. Jika jatah atau bantuan dari pemerintah berhenti, bubar pula koperasinya.

Model koperasi lain yang dikembangkan oleh pemerintah adalah koperasi fungsional berbasis profesi, dimana yang menonjol di antaranya adalah koperasi karyawan dan pegawai negeri. Koperasi fungsional ini kemudian menjadi basis bagi perkembangan dua model koperasi tradisional, yaitu koperasi kredit atau simpan pinjam, dan koperasi konsumsi atau perdagangan. Basis dari koperasi pada dasarnya ada dua, yaitu orang atau sumberdaya manusia, dan kedua adalah tingkat pendapatan yang menjadi sumber tabungan. Basis yang pertama melahirkan kompetensi atau profesionalitas, yang akan menghasilkan pelayanan dan kegiatan usaha. Pada ujungnya, basis ini akan mendorong munculnya diversifikasi usaha. Sementara, dari basis kedua dapat dihimpun modal yang kemudian bisa diputar dalam bentuk kegiatan simpan pinjam. Modal ini dapat pula dipergunakan untuk investasi usaha, baik langsung dijalankan oleh koperasi atau melalui perseroan terbatas. Demikian pula modal ini dapat dipakai oleh anggota untuk menjalankan usaha, baik perdagangan, industri, atau pelayanan jasa. Jadi, secara umum, kedua basis itu akan mendorong berkembangnya koperasi serba usaha, walaupun serba usaha itu biasanya didasarkan pada inti usaha (core-business) tertentu.

Di luar semua kerangka program pemerintah tadi, di masa Orde Baru telah pula berkembang koperasi-koperasi yang berdiri atas inisiatif perorangan, kelompok, atau komunitas khusus yang bersifat homogen. Mereka mendirikan koperasi biasanya dikarenakan dua faktor, yaitu berdasar pengamatan atas potensi pasar dan kebutuhan masyarakat, atau bisa disebut sebagai faktor demand-side; dan juga karena kemampuan produksi dan pelayanan yang dimilikinya, atau yang bisa disebut sebagai faktor supply-side. Potensi pasar itu misalnya permintaan pabrik pengolahan susu terhadap bahan susu perah dari sapi ternak, pelayanan jasa transportasi kota, serta kebutuhan masyarakat lainnya, seperti bahan pangan atau aneka barang kelontong dan alat-alat kantor. Sedangkan 
kemampuan produksi misalnya adalah mengolah bahan kulit dan plastik menjadi barang kerajinan. Adapun pelayanan jasa misalnya berupa penyediaan tenaga kerja, jasa telekomunikasi, atau distribusi produkproduk industri.

\section{KOPERASI KREDIT DI INDONESIA}

Dalam sejarah perkembangan koperasi di Indonesia, meski masih bersifat embrional, koperasi yang pertama kali lahir adalah dalam bentuk lembaga perkreditan rakyat, yaitu De Poerwokertosche Hulp en Spaarbank Der Inlandsche Hoofden di Purwokerto pada tahun 1895, atas prakarsa Patih Aria Wiriaatmaja, yang mendapat dukungan dari atasannya, Asisten Residen Purwokerto, E. Sieburg. Ketika Sieburg digantikan oleh De Wolf van Westerrode, pejabat baru itu juga memiliki perhatian yang sama terhadap kredit rakyat. Westerrode bahkan memiliki obsesi untuk mewujudkan koperasi kredit pertanian sebagaimana yang digagas oleh Friedrich Wilhelm Raiffeisen (1818-1888) di Jerman. Oleh karena itu, cakupan De Poerwokertosche Hulp en Spaarbank Der Inlandsche Hoofden kemudian diperluas hingga menjangkau desa-desa dan mencakup pula kredit pertanian, sehingga pada 1896 telah berdiri De Poerwokertosche Hulp, Spaar en Landbouw Creditbank (Bank Simpan Pinjam dan Kredit Pertanian Purwokerto), sebuah koperasi kredit model Raiffeisen, yang merupakan model koperasi tradisional pertama di Indonesia. Selain model Raiffeisen, di Indonesia juga berkembang model lain, yaitu model koperasi konsumsi Schulze Delitz yang tumbuh dari bawah, khususnya dari kalangan kaum buruh dan penduduk perkotaan yang pada umumnya merupakan konsumen. Model koperasi ini kemudian berkembang menjadi koperasi perdagangan. Kedua model koperasi tradisional itu mula-mula berkembang di kalangan pegawai negeri yang dipelopori oleh golongan priyayi dan dikemudian hari berkembang menjadi koperasi fungsional. Koperasi atau cikal bakal koperasi itu lahir sebagai respon terhadap kondisi kemiskinan atau tingkat kesejahteraan yang rendah. Ini adalah asal-usul aliran pemikiran koperasi yang memandang koperasi sebagai lembaga pengentasan masyarakat dari kemiskinan atau tingkat kesejahteraan yang rendah.

Mohammad Hatta, Bapak Koperasi Indonesia yang juga arsitek Pasal 33 UUD 1945, berdasarkan pengalaman perkembangan koperasi sejak awal abad ke-2o sebenarnya sudah membayangkan tahap-tahap perkembangan ekonomi di masa kemerdekaan. Pada mulanya, masyarakat akan cenderung mengembangkan koperasi konsumsi. Namun koperasi konsumsi itu akan cenderung gagal, karena kekurang-terampilan berdagang dan juga modal yang minim. Lalu akan berkembang koperasi simpan pinjam dari orangorang yang memiliki uang, sehingga terhimpun modal untuk memperkuat 
perdagangan. Setelah itu baru timbul koperasi produksi di bidang pertanian, pertukangan, kerajinan, dan industri. Koperasi akan merupakan persemaian usaha-usaha individual. Koperasi itu berangsur-angsur akan menjadi usaha skala menengah dan besar.

Dalam teori maupun realitas, koperasi, sebagai organisasi kumpulan orang, hanya bisa berkembang apabila anggotanya memiliki usaha atau memiliki penghasilan yang lebih besar dari kebutuhan konsumsinya, sehingga mereka bisa menabung. Terutama bagi koperasi simpan pinjam atau koperasi kredit, persyaratan ini penting untuk diperhatikan. Sedangkan, bagi koperasi-koperasi yang berbasiskan di daerah-daerah kantong kemiskinan, mereka tentu memerlukan modal dari luar untuk bisa memberikan kredit kepada para anggotanya yang memiliki usaha. Pinjaman-pinjaman yang diberikan itu diharapkan bisa bergulir dengan hasil lebih besar sehingga bisa kembali ke koperasi dalam bentuk simpanan. Dana awal itu bisa berasal dari Bank Indonesia (di masa lalu), pemerintah, badan usaha, perorangan yang memiliki kelebihan uang, atau dana sumbangan, termasuk di dalamnya zakat, infak, sedekah, dan wakaf. Dalam masyarakat tradisional, kredit biasanya berasal dari orang kaya atau pengusaha dimana mereka meminjamkan uangnya dengan tingkat bunga tinggi. Mereka disebut sebagai pembunga uang, tukang kredit, atau orang yang melakukan mindering, yang dalam bahasa Belanda disebut woeker alias rentenir. Inilah yang disebut sistem riba oleh Sjafruddin Prawiranegara. Dalam lingkungan seperti itu koperasi dimaksudkan untuk menggantikan rentenir dalam melayani kebutuhan kredit dengan bunga rendah.

Karena pada zaman Belanda penduduk kota apalagi desa berpendapatan rendah, maka koperasi kredit sulit berkembang. Atas dasar itulah maka Sumitro Djojohadikusumo berpendapat bahwa kredit itu sendiri bukan pemecahan masalah, atau dengan perkataan lain bukan solusi, melainkan bagian dari masalah. Oleh karena itu ia mengemukakan bahwa diperlukan pembangunan ekonomi terlebih dahulu untuk meningkatkan pendapatan rakyat. Sebagai tahap awal, agar rakyat bisa melakukan usaha, diperlukan kredit kecil yang modalnya berasal dari pemerintah dan Bank Indonesia. Walaupun demikian, pada waktu itu, rakyat sendiri masih bisa mengumpulkan modal melalui tabungan koperasi dari orang-orang yang mempunyai dana untuk diputarkan, sehingga berkembang lembaga perkreditan rakyat yang ternyata bisa ribuan jumlahnya.

Pembangunan ekonomi sebagaimana yang dimaksudkan oleh Sumitro baru bisa dilakukan pada masa Orde Baru yang menghasilkan pertumbuhan ekonomi-meskipun tidak bersifat merata hingga ke tingkat bawah. Hasil pembangunan itu bisa dilihat dari meningkatnya pendapatan masyarakat dan berkurangnya persentase penduduk yang hidup di bawah garis kemiskinan (dari sekitar 60\% pada awal 1970-an menjadi sekitar $11 \%$ pada 
tahun 1997). Hal ini berarti timbulnya kantong-kantong atau lapisan dana pada masyarakat yang bisa dihimpun. Maka pada tahun 1984, Bank Indonesia, di masa Arifin Siregar, melakukan reformasi moneter yang intinya adalah memberi kesempatan dan mendorong bank-bank untuk menghimpun dana masyarakat dengan membebaskan mereka dalam menentukan suku bunga simpanan dan kredit. Sejak itu komponen dana pihak ketiga pada bank meningkat drastis dan merupakan potensi untuk melakukan ekspansi kredit kepada masyarakat. BRI yang lahir dari lembaga perkreditan rakyat di zaman Hindia Belanda, Algemeene Volkscredietbank, kemudian membuat proyek penghimpunan dana tabungan di daerah miskin, seperti di Gunung Kidul, Yogyakarta, dan di Wonogiri, Jawa Tengah, yang ternyata berhasil. Hal ini menunjukkan bahwa di kalangan masyarakat terkandung kantong-kantong dana. Dari perkembangan itu dapat ditarik kesimpulan bahwa koperasi yang anggotanya terdiri dari pelaku-pelaku ekonomi rakyat memiliki potensi yang besar untuk berkembang.

Koperasi yang orientasinya melayani kebutuhan rakyat kecil terasa dibutuhkan, karena menurut hasil pengamatan, dana yang dihimpun oleh bank-bank dari masyarakat bawah disinyalir telah disalurkan kepada perusahaan-perusahaan besar. Demikian pula uang yang berasal dari lapisan masyarakat di tingkat lokal telah tersedot dan terkonsentrasi di atas atau pusat. Dengan perkataan lain telah terjadi aliran dana ke atas (trickleup). Sementara itu perekonomian rakyat sejak awal abad ke-21 mengalami kebangkitan kembali dalam bentuk ekonomi kreatif. Untuk bisa berkembang lebih lanjut pelaku ekonomi rakyat membutuhkan modal. Karena itu arah kebijaksanaan moneter perlu dipikirkan ulang. Pertama, perlu segera dilakukan proses daur ulang dana-dana di pusat untuk diedarkan ke bawah dalam bentuk kredit kecil dan mikro, atau proses trickle-down. Kedua, dengan menahan dana yang terkumpul di bawah agar tetap beredar di tingkat bawah. Lembaga yang instrumental untuk melembagakan kebijaksanaan itu adalah koperasi kredit.

Sementara itu menurut laporan ICA pada 2004, sejumlah 40\% koperasikoperasi yang termasuk ke dalam Global 300 adalah koperasi kredit dan asuransi, diikuti oleh koperasi pertanian sebesar $25 \%$, dan kemudian koperasi perdagangan ritel dan grosir sebesar 15\%. Di Indonesia sendiri, di masa Orde Baru, koperasi yang menonjol dan sukses adalah juga koperasi kredit yang tumbuh tanpa bantuan atau fasilitas pemerintah. Koperasikoperasi kredit itu yang terpenting adalah koperasi kredit (Kopdit) model credit union (CU) sebagaimana yang berkembang di Kanada dan Amerika Serikat, yang total gabungan aset nasionalnya mencapai sekitar Rpı triliun. Kelompok koperasi ini terdiri dari 208 koperasi primer beranggotakan di atas seribu orang dengan nilai aset di atas satu miliar rupiah. Contohnya adalah Koperasi Simpan Pinjam "Jasa” (Kospin Jasa) Pekalongan yang 
asetnya sekitar Rp1,8 triliun, dengan anggota 8.145, dan Koperasi Setia Bhakti Wanita, Surabaya, yang beranggotakan 10.988 orang dengan nilai aset Rp1,o9 triliun.

Salah satu bentuk koperasi yang kini berkembang pesat adalah credit union (CU), yang berkembang baik di desa maupun di kota. Keistimewaan koperasi ini adalah mampu berkembang di kalangan masyarakat yang belum berkembang perekonomiannya, baik kawasan tertinggal dan daerah terpencil, seperti masyarakat di tengah dan di tepi hutan Kalimantan Barat yang pada umumnya miskin. Banyak koperasi primer CU ini yang berhasil berkembang secara swadaya tanpa-bahkan menolak-bantuan pemerintah, meski untuk itu mereka berkembang agak lama dan mengalami banyak rintangan. Letak keberhasilan mereka yang utama adalah pada kemampuannya untuk bertahan (sustainability) secara mandiri. Mereka berhasil memberdayakan anggota lewat pendidikan berbasis prinsip-prinsip CU. Perkembangan koperasi model ini bisa dilihat dari pertambahan jumlah anggota, jumlah nilai tabungan, volume usaha, dan nilai aset. Pada mulanya CU hanya melayani kredit konsumtif, tetapi kemudian melayani kredit produktif atau kredit usaha-bahkan ada CU yang mensyaratkan kredit hanya untuk anggota yang memiliki usaha. Kopdit Lantang Tipo di Kalimantan Barat, misalnya, yang beranggotakan 104.927 orang dengan nilai aset Rp1,o1 triliun, dengan demikian nilai kepemilikan aset koperasi Rp9,6 juta per orang.

Pencapaian CU lebih nampak pada perkembangan koperasi kredit pada tingkat primer, seperti koperasi kredit Kodanua (Jakarta), KSP Berkat (Bulukumba, Sulawesi Selatan), CU Tri Tapang Kasih (Kapuas, Kalimantan Barat), CU Semandang Jaya (Simpang Hulu, Kalimantan Barat), CU Pancur Kasih (Pontianak, Kalimantan Barat), Lantang Tipo (Kalimantan Barat), CU Keling Kumang (Kalimantan Barat), CU Khatulistiwa Bakti (Pontianak, Kalimantan Barat), dan CU Obor Mas (Maumere, NTT). Keistimewaan dari koperasi kredit dalam bentuk CU adalah pertama, peranannya dalam membudayakan simpanan untuk berbagai keperluan. Kedua, kualitas pelayanannya yang akrab dan ramah tetapi efisien seperti halnya lembaga perbankan umum. Anggotanya membentuk komunitas yang akrab dan merupakan forum musyawarah dalam usaha rumah tangga. Indikator vitalnya tergambar pada Tabel 2.

Kospin Jasa, Pekalongan, salah satu koperasi simpan pinjam besar di Jawa, mula-mula beranggotakan para pedagang dan pengusaha batik di Pekalongan dan sekitarnya. Koperasi ini tidak mengutamakan jumlah anggota, tetapi melayani nasabah non-anggota yang jumlahnya banyak. Dengan demikian letak keistimewaan koperasi yang sukses ini adalah kemampuannya melayani kebutuhan masyarakat umum, khususnya pedagang dan pengusaha, dengan mutu pelayanan prima, termasuk sudah bekerja menggunakan sistem on-line banking. Kekuatan koperasi ini 
terletak pada pengelolaan koperasi secara profesional berdasarkan prinsipprinsip perbankan yang prudent. Dalam jangka waktu lama, koperasi ini hanya boleh beroperasi di wilayah kerja bekas Karesidenan Pekalongan, Semarang dan Solo, dan kemudian berkembang pesat setelah diizinkan untuk beroperasi secara nasional. Perkembangan koperasi ini bisa dilihat dari bertambahnya jumlah kantor cabang serta cabang pembantu, serta jenis produk yang dijual-misalnya, kini Kospin Jasa Pekalongan telah membuka unit syari'ah di beberapa kota. Nilai aset per anggota adalah Rp218 juta.

TABEL 2

INDIKATOR 9 KOPDIT TERPILIH, DESEMBER, 2009

(DALAM JUTA RUPIAH)

\begin{tabular}{|c|l|c|c|c|}
\hline No. & \multicolumn{1}{|c|}{ Nama Kopdit } & $\begin{array}{c}\text { Jumlah } \\
\text { Anggota }\end{array}$ & Asset & $\begin{array}{c}\text { Pinjaman } \\
\text { Beredar }\end{array}$ \\
\hline 1 & KSP Kodanua (Jakarta) & 18.477 & 101.703 & 283.603 \\
\hline 2 & KSP Berkat (Bulukumba, Sulsel) & 11.472 & 86.506 & 86.812 \\
\hline 3 & $\begin{array}{l}\text { CU Tri Tapang Kasih (Kapuas Hulu, } \\
\text { Kalbar) }\end{array}$ & 13.679 & 65.371 & 52.818 \\
\hline 4 & $\begin{array}{l}\text { CU Semandang Jaya (Simpang Hulu, } \\
\text { Ketapang, Kalbar) }\end{array}$ & 16.575 & 65.588 & 54.873 \\
\hline 5 & CU Pancur Kasih (Pontianak, Kalbar) & 79.944 & 729.027 & 606.276 \\
\hline 6 & CU Lantang Tipo (Kalbar) & 91.801 & 771.188 & 573.066 \\
\hline 7 & CU Keling Kumang (Kalbar) & 77.438 & 353.811 & 283.661 \\
\hline 8 & CU Khatulistiwa Bakti (Pontianak, Kalbar) & 23.810 & 142.740 & 115.410 \\
\hline 9 & CU Obor Mas (NTT) & 8.647 & 147.059 & 125.273 \\
\hline
\end{tabular}

Koperasi Setia Bhakti Wanita (SBW), Surabaya, sebenarnya adalah koperasi kredit yang beranggotakan perempuan, khususnya perempuan yang berdagang di pasar-pasar tradisional. Dengan demikian, kekuatan koperasi ini terletak pada anggotanya yang punya usaha, khususnya berdagang. Selain itu, dengan keanggotaan yang homogen (perempuan), koperasi ini juga memiliki modal sosial (social capital) kuat, yaitu sikap kesalingpercayaan atau amanah (social trust atau mutual-trust) secara horisontal maupun vertikal. Dalam koperasi ini keanggotaan individu berhimpit dengan kenasabahan. Dengan perkataan lain, para anggota adalah sekaligus produsen dan konsumen. Dengan anggota sebanyak 10.998 orang dan aset Rp1o9,2 miliar, maka kepemilikan aset per anggota adalah Rp9,9 juta.

Koperasi produksi yang juga dinilai cukup berhasil adalah KPBS (Koperasi Peternak Bandung Selatan), yaitu koperasi peternak susu di Pengalengan, Bandung. Basis koperasi ini adalah peternak susu yang terkonsentrasi di suatu wilayah kecamatan di daerah pegunungan yang cocok untuk peternakan susu perah. Peternakan itu sendiri sudah 
berkembang sejak tahun 18oo-an, sehingga anggota-anggota koperasi tadi telah berpendapatan di atas rata-rata dan oleh karenanya mampu menabung. Dengan modal tersebut, koperasi ini mampu mendirikan unit pemrosesan yang menciptakan nilai tambah dan kualitas bahan baku susu olahan bermutu standar. Melalui koperasi itu peternak susu bisa memasarkan produk dalam skala besar ke industri pengolahan susu, bahkan mereka kemudian bisa memproses produk susu olahan sendiri. KPBS mampu tampil sebagai koperasi berhasil pada awal abad ke-21. Dengan anggota sebanyak 6.351 orang dan nilai aset sebesar Rp206,99 miliar, maka nilai kepemilikan aset rata-rata adalah sebesar Rp32,59 juta. Sebenarnya koperasi susu berpotensi untuk menjadi koperasi skala global, dengan mengambil contoh koperasi susu di India yang masuk ke dalam daftar koperasi Global 300 yang dirilis ICA.

TABEL 3

PERKEMBANGAN GKKI SEJAK 2000-2009

\begin{tabular}{|c|c|c|c|c|c|c|}
\hline \multirow{2}{*}{ Tahun } & \multicolumn{6}{|c|}{ Jumlah } \\
\cline { 2 - 7 } & Kopdit & Anggota & $\begin{array}{c}\text { Simpanan } \\
\text { (dalam juta } \\
\text { rupiah) }\end{array}$ & $\begin{array}{c}\text { Pinjaman } \\
\text { Beredar } \\
\text { dalam juta } \\
\text { rupiah) }\end{array}$ & $\begin{array}{c}\text { Kekayaan } \\
\text { (dalam juta } \\
\text { rupiah) }\end{array}$ & $\begin{array}{c}\text { Cadangan } \\
\text { (dalam juta } \\
\text { rupiah) }\end{array}$ \\
\hline 2000 & 1.090 & 256.327 & 128.114 & 189.670 & 242.258 & 15.510 \\
\hline 2001 & 1.071 & 295.924 & 258.433 & 272.124 & 358.154 & 18.925 \\
\hline 2002 & 1.095 & 335.838 & 363.898 & 395.722 & 518.072 & 25.782 \\
\hline 2003 & 1.039 & 378.115 & 543.826 & 577.532 & 753.754 & 31.804 \\
\hline 2004 & 1.041 & 479.531 & 940.155 & 957.835 & 1.227 .423 & 43.831 \\
\hline 2005 & 980 & 603.728 & 1.459 .245 & 1.483 .033 & 1.874 .916 & 51.821 \\
\hline 2006 & 1.041 & 780.110 & 2.339 .391 & 2.538 .759 & 2.854 .738 & 75.000 \\
\hline 2007 & 972 & 966.704 & 3.440 .681 & 3.238 .624 & 4.123 .513 & 90.526 \\
\hline 2008 & 949 & 1.154 .208 & 4.845 .951 & 4.603 .336 & 5.754 .926 & 126.810 \\
\hline 2009 & 940 & 1.220 .335 & 5.420 .320 & 5.095 .793 & 6.323 .136 & 153.961 \\
\hline (Juni) & 94036 \\
\hline
\end{tabular}

Pada awal abad ke-21, CU yang pada masa Orde Baru tidak mendapat perhatian, kini tampil sebagai koperasi raksasa di Indonesia. Jika digabung menjadi satu, dilihat dari nilai aset dan volume usahanya, gabungan CU yang ada di Indonesia bisa "masuk" ke dalam koperasi Global 300 dengan catatan telah dinilai kontribusinya kepada masyarakat sebagai tanggung jawab sosial koperasi (cooperative social responsibility). Gambaran perkembangan CU secara terkonsolidasi tercermin dalam indikator vital Gabungan Koperasi Kredit Indonesia (GKKI) per Juni 2008 sebagaimana dimuat dalam Tabel 3. 


\section{KOPERASI KOMUNITAS}

Koperasi yang kini berkembang sebagai koperasi sukses yang tumbuh dari prakarsa komunitas adalah KISEL, yaitu koperasi karyawan PT Telkomsel, yang volume usahanya kini mencapai Rp2,7 triliun, meskipun baru dibentuk pada tahun 1997. Koperasi ini sebenarnya merupakan gabungan dari 14 koperasi di lingkungan PT Telkomsel dengan wilayah kerja seluruh Indonesia. Koperasi Kisel mempunyai anggota sebanyak 3.712 orang. Mitra kerja utama koperasi ini adalah PT Telkomsel itu sendiri dan bertindak sebagai vendor atau menyediaan kebutuhan BUMN telekomunikasi itu.

Kisel secara umum mempunyai dua wajah. Pertama adalah wajah koperasi yang bertujuan untuk meningkatkan kesejahteraan anggotanya. Kedua adalah wajah korporasi atau unit komersial yang bertujuan memperoleh laba, sehingga oleh karenanya berwatak bisnis. Basis keanggotaan koperasi ini adalah kelompok profesional di bidang telekomunikasi, sehingga koperasi ini didukung oleh anggota yang berpendapatan di atas rata-rata, dimana mereka memiliki kemampuan untuk menabung. Dari tabungan itulah bisa dihimpun modal. Dengan modal itu koperasi melakukan kegiatan bisnis berbasis pasar institusional, yaitu perusahaan-perusahaan yang membutuhkan pelayanan jasa telekomunikasi. Kekuatan koperasi ini adalah profesionalitas para pengurus dan anggotanya yang memahami prinsip-prinsip bisnis pelayanan jasa telekomunikasi, sebuah bisnis yang dewasa ini telah dan semakin berkembang pesat.

Pada dasarnya Koperasi Kisel bergerak di tiga bidang usaha. Pertama, di bidang channel distribution (CD) Kisel menjadi medium bagi industri telekomunikasi. Kedua, di bidang jasa infrastruktur teknologi informasi (IT infrastructure service), Kisel menjadi medium bagi operator telekomunikasi untuk menyelesaikan bagian dari proses bisnis infrastrukturnya. Dan ketiga, di bidang general service (GS), Kisel menjadi medium bagi semua pelaku usaha terkait dengan kebutuhan terhadap pelayanan umum. Kesemua bidang usaha itu membutuhkan pengelolaan yang profesional di bidang teknologi informasi, sehingga Kisel memiliki daya saing yang tinggi berbasis kompetensi. Dengan anggota 3.712 orang, dan nilai asset sebesar Rp580,700 miliar, maka nilai aset per anggotanya adalah Rp156 juta.

Contoh koperasi sukses lainnya yang didirikan oleh komunitas adalah Koperasi Karyawan Indosat (Kopindosat), yang didirikan pada tahun 1994 sewaktu PT Indosat masih berstatus sebagai BUMN, belum diprivatisasi. Pada tahun 2010, koperasi ini telah memiliki volume usaha senilai Rp1.054 miliar. Berbeda dengan koperasi pada umumnya, organisasi manajemen Kopindosat merupakan hasil integrasi antara model kepengurusan koperasi dengan kedireksian perseroan terbatas, dimana pengurus langsung bertindak sebagai direksi, dan dewan pengawas sebagai dewan komisaris, 
sehingga memperpendek jenjang organisasi manajemen. Dengan anggota sebanyak 4.219 orang, dengan nilai asset Rp361,85 miliar, maka kepemilikan asset per anggota adalah Rp86 juta.

Berbeda dengan Kisel, bisnis inti Kopindosat adalah penyedia tenaga kerja, bukan saja untuk PT Indosat, tetapi juga untuk perusahaanperusahaan besar lainnya, sehingga Kopindosat tidak tergantung kepada PT Indosat, termasuk tidak tergantung kepada statusnya yang kini telah menjadi perusahaan asing. Bisnis inti ini menyumbang sebesar 54 persen dari total SHU, sementara 15 persen lainnya berasal dari bisnis distribusi voucher seluler, dan sisanya berasal dari general trading serta usaha simpan pinjam (USP). Bisnis USP itu berbasis sistem keuangan syari'ah dan telah menyalurkan pinjaman sebesar Rp6,852 miliar. Dengan pola usaha itu, maka Kopindosat menciptakan model koperasi yang menyimpang dari pola tradisional, meskipun di sisi yang lain ia masih menjalankan model sebagai koperasi konsumsi, perdagangan dan simpan pinjam.

Serupa dengan Koperasi Kisel adalah Koperasi Tankers Perkapalan di Tanjung Priok yang didirikan pada tahun 1983. Koperasi ini mula-mula bergerak di bidang tradisional simpan pinjam (KSP). Sebelum merambah ke bidang lain, koperasi ini sempat macet. Pada tahun 2005, koperasi ini bangkit kembali, yang diikuti dengan pergantian pengurus baru dan perubahan AD/ART terkait keanggotaan. Selain itu unit usaha ditata-ulang dengan manajemen yang profesional. Bidang usaha yang kemudian melebar bersinergi dengan induk perusahaan, yaitu PT Pertamina, dengan membentuk tiga anak perusahaan yang menggarap tiga bidang usaha berbeda tetapi masih berkaitan dengan bisnis induk Pertamina. Tiga anak perusahaan itu adalah, pertama PT Perta Samudera yang bergerak di bidang jasa perbaikan kapal tanker milik PT Pertamina Perkapalan. Kedua, PT Tanker Mandiri yang bergerak di bidang outsourcing, khususnya tenaga sekuriti pengamanan perusahaan dan pengadaan material. Dan ketiga, PT Tanker Samudera Mandiri yang bergerak di bidang perdagangan, antara lain pengadaan komputer, peralatan transmisi dan telekomunikasi, peralatan civil engineering, serta mesin kapal dan alat-alat bantunya. Di samping itu juga dibentuk usaha jasa ekspedisi, pergudangan, pengepakan, persewaan mesin dan perawatan jaringan operasi komputer. Dengan usaha bisnis itu, maka Koperasi Tankers, melalui tiga unit usahanya yang berbentuk perseroan terbatas itu, berhasil mencetak Sisa Hasil Usaha (SHU) sebesar Rp3,670 miliar. Dengan anggota sebanyak 841 orang dan nilai aset sebesar Rp44,942 miliar, maka nilai kepemilikan aset per anggota adalah Rp93 juta. Dalam kasus ini nampak bahwa perkembangan koperasi terletak pada operasi bisnisnya yang berkaitan dengan bisnis perusahaan induk. Di situ beda antara koperasi dengan perseroan terbatas adalah bahwa dalam koperasi, pemilik badan usaha dan penerima keuntungan adalah anggota koperasi yang juga merupakan karyawan BUMN yang jumlahnya banyak. 
Selain itu, dalam kasus di atas, koperasi juga telah menciptakan lapangan kerja bagi orang-orang di luar perusahaan, sehingga koperasi telah berperan sebagai lembaga distribusi pendapatan dan kekayaan.

Koperasi karyawan PT Semen Gresik, yang disebut Koperasi Warga Semen Gresik (KWSG) juga kurang lebih serupa. Bedanya dengan koperasi karyawan Telkomsel dan Pertamina adalah koperasi ini terutama bergerak di bidang pemasaran produk PT Semen Gresik, yaitu semen, dan juga bahan-bahan bangunan lainnya di luar semen yang berasal dari pabrik lain. Sebenarnya koperasi ini sudah dibentuk sejak lama, pada tahun 1963, yang mula-mula merupakan koperasi konsumsi bahan-bahan pokok dan sayuran untuk melayani kebutuhan warga. Pada tahun 1980 koperasi ini bergerak dalam bisnis pertokoan dan penjahitan untuk memenuhi kebutuhan baju seragam perusahaan. Lima tahun kemudian, pada tahun 1985, koperasi ini memulai usaha baru, yaitu simpan pinjam.

Perkembangan ini mengikuti pola tradisional koperasi, yaitu konsumsai dan simpan pinjam. Sayap konsumsi itu kemudian berkembang menjadi bisnis perdagangan umum yang pada tahun 1992 memusatkan diri pada perdagangan bahan bangunan. Setelah menunjukkan kinerja profesionalnya, maka KWSG baru mengakses ke dalam industri perusahaan induknya, dengan mulai memasarkan semen dan kemudian juga mengakses ke produk bahan bangunan lainnya, mencakup produk dari dua belas pabrik bahan bangunan. Untuk menunjang fungsi perdagangan, KWSG kemudian membentuk unit usaha ekspedisi. Dan untuk menunjang usaha transportasinya itu, KWSG membentuk unit perbengkelan dan pergudangan. Perkembangan yang menarik adalah bahwa unit perdagangan umum itu kemudian berkembang menjadi unit ritel modern dengan nama $V$-Mart yang menjalin kerjasama dengan toko ritel lainnya di Jawa Timur dan Madura, bahkan sampai ke Purwodadi di Jawa Tengah. Dengan melengkapi sistem supply-chain ini, unit perdagangan bahan bangunan menangani berbagai produk hingga ke batu bara dan bahan bangunan inovatif, seperti bahan bangunan dari sekam padi. Di sini, KWSG menjadi media untuk mengembangkan entrepreneurship yang menciptakan diversifikasi usaha melalui sistem koperasi. Pada yahun 2010, struktur bisnis dan pendapatan KWSG tergambar dalam tabel di bawah. Dari tabel tersebut kita bisa melihat bahwa dengan jumlah anggota sebanyak 5.819 orang dan nilai asset sebesar Rp417,953 miliar, maka nilai kepemilikan asset per anggota adalah Rp72 juta. 
TABEL 4

STRUKTUR PENDAPATAN

KOPERASI WARGA SEMEN GRESIK, 2010

\begin{tabular}{|c|l|c|}
\hline No. & \multicolumn{1}{|c|}{ Bidang Usaha } & Persentase \\
\hline 1 & Perdagangan Bahan Bangunan & 82,27 \\
\hline 2 & Ekspedisi & 6,74 \\
\hline 3 & Perdagangan Umum & 6,14 \\
\hline 4 & Percetakan, Jasa Boga & 2,63 \\
\hline 5 & Simpan Pinjam & 1,76 \\
\hline
\end{tabular}

Nampak dari tabel di atas bahwa simpan pinjam KWSG yang beranggotakan 463 orang karyawan itu hanya memberi sumbangan pendapatan terkecil kepada koperasi. Namun, kinerja unit simpan pinjam itu nampak meyakinkan sebagai tergambar dalam tabel bertikut.

TABEL 5

PRODUK SIMPANAN DAN NILAI TOTAL SIMPANAN

UNIT SIMPAN PINJAM KWSG

(Dalam Juta Rupiah)

\begin{tabular}{|c|l|r|r|r|r|}
\hline No. & \multicolumn{1}{|c|}{ Uraian } & $\begin{array}{c}\text { Tahun } \\
\mathbf{2 0 1 0}\end{array}$ & Persentase & $\begin{array}{c}\text { Tahun } \\
\mathbf{2 0 0 9}\end{array}$ & Persentase \\
\hline 1 & Simpanan Pokok & 582 & 1 & 579 & 2 \\
\hline 2 & Simpanan Wajib & 5.686 & 13 & 4.469 & 13 \\
\hline 3 & Simpanan Khusus Permanen & 6.337 & 14 & 2.145 & 6 \\
\hline 4 & Simpanan Khusus Berjangka & 4.001 & 9 & 2.875 & 8 \\
\hline 5 & Simpanan Sukarela & 27.532 & 62 & 24.377 & 71 \\
\hline \multicolumn{2}{|c|}{ Total } & 44.138 & 100 & 34.445 & 100 \\
\hline
\end{tabular}

Nampak dari tabel di atas bahwa simpanan terbesar adalah dari simpanan sukarela yang mencakup 62 persen dari total simpanan.

Koperasi Pegawai Negeri Sipil (KPNS) merupakan varian koperasi fungsional lainnya. Salah satu KPNS yang tergolong sukses adalah Koperasi Pegawai Negeri Universitas Negeri Makasar (UNM) yang didirikan pada tahun 1982 dengan jumlah anggota awal 100 orang. Pada tahun 2010, KPNSUNM telah membentuk asset total sebesar Rp51,3 miliar dengan volume usaha sebesar Rp4o miliar dan SHU sebesar Rp236,8 juta. Inti usaha (corebusiness) koperasi ini adalah simpan pinjam, yang merupakan bidang usaha tradisional koperasi. Dengan usaha keuangan ini, yang bersandar pada prinsip keunggulan pelayanan, maka koperasi ini mendasarkan operasinya pada lima prinsip pelayanan prima (excellent service), sebagaimana dirumuslan dalam tabel berkut. 
TABEL 6

PRINSIP-PRINSIP PELAYANAN PRIMA

KPNS UNIVERSITAS NEGERI MAKASSAR

\begin{tabular}{|c|l|l|}
\hline No. & \multicolumn{1}{|c|}{ Prinsip } & \multicolumn{1}{|c|}{ Uraian } \\
\hline $\mathbf{1}$ & In hour service & $\begin{array}{l}\text { Melayani kebutuhan pinjaman anggota secara } \\
\text { cepat, hanya menghabiskan waktu 5 menit. }\end{array}$ \\
\hline 3 & Zero Complain & $\begin{array}{l}\text { Menekan peluang timbulnya keluhan dengan } \\
\text { memberikan pelayanan terbaik melalui } \\
\text { senyum, salam, sapa, simpati dan serius. }\end{array}$ \\
\hline 4 & Soft-care & $\begin{array}{l}\text { Setiap dokumen peminjaman harus melalui } \\
\text { persetujuan karyawan dan mengurus sesuai } \\
\text { dengan bidang kerjanya. }\end{array}$ \\
\hline 5 & Welfare member & $\begin{array}{l}\text { Memberikan pelayanan secara sopan dan } \\
\text { santun. }\end{array}$ \\
\hline
\end{tabular}

Prinsip di atas pada mulanya hanya diterapkan pada unit Usaha Simpan Pinjam (USP) saja, tetapi kemudian diterapkan juga dalam pengembangan bisnis di sektor riil, yaitu bidang jasa, perdagangan umum, distributor, kontraktor, developer dan berbagai usaha kecil, seperti perbengkelan, pertukangan, pengolahan hasil pertanian, percetakan, dan penerbitan. Bidang-bidang usaha itulah yang dikerjakan oleh anggota koperasi yang mencapai jumlah sekitar 100 orang, dengan nilai aset Rp53,1 miliar maka nilai kepemilikan per anggota adalah Rp531 juta. Dengan demikian, maka koperasi merupakan wadah untuk mengembangkan visi anggota dalam berusaha. Berdasarkan lima prinsip pelayanan yang dianutnya, anggota kemudian mengembangkan jaringan copmart, atau mini-market koperasi.

Koperasi fungsional, selain berkembang di lingkungan BUMN, juga berkembang di lingkungan perusahaan asing, misalnya pertambangan, sebagaimana yang misalnya hadir di lingkungan PT Freeport di Papua. Usaha pertambangan itu antara lain melahirkan PT Kuala Pelabuhan Indonesia. Perseoran terbatas ini memiliki serikat pekerja yang kemudian membentuk Koperasi Karyawan (Kopkar) Jayawijaya pada tahun 1997. Dengan demikian, para pekerja, dalam usahanya untuk meningkatkan kesejahteraan mereka menempuh dua jalur organisasi, pertama serikat kerja yang menitik-beratkan pemenuhan hak-hak pekerja berdasarkan hubungan kerja industrial, dan kedua adalah dengan membentuk koperasi untuk meningkatkan kesejahteraan. Ini bisa dijadikan model sebagai dua sayap kegiatan serikat pekerja.

Sebagaimana Kopkar pada umumnya, unit usaha awal yang dilakukan adalah USP yang seterusnya merupakan usaha inti. Namun dari usaha inti yang merupakan sektor tradisional koperasi ini kemudian berkembang juga 
dua sektor kembar tradisional lainnya, yaitu usaha konsumsi, dan kemudian usaha perdagangan, yang ditandai dengan pendirian perusahaan pemasok ikan mentah, PT Pangansari Utama, yang memasok kebutuhan ikan mentah untuk proyek-proyek PT Freeport, dan juga memasok bahan-bahan makanan lain bagi perusahaan pertambangan asing lainnya. Berbasis usaha koperasi itu, Kopkar Jayawijaya berhasil meningkatkan permodalan USP hingga mencapai Rp5 miliar. Selain memasok bahan pangan, Kopkar ini juga kemudian melebarkan usahanya ke sektor bisnis transportasi dan pertokoan barang-barang konsumsi kebutuhan masyarakat.

Inti usaha Kopkar Jayawijaya adalah tetap USP, yang wilayah operasinya kemudian meluas ke beberapa wilayah untuk melayani kebutuhan kredit usaha kecil setempat. Pada tahun 2010, pinjaman yang diberikan mencapai Rp3o,1 miliar berbasiskan modal sendiri, tanpa modal dari luar. Kekuatan Kopkar ini terletak pada jumlah anggotanya yang mencapai 937 orang. Dengan nilai aset sebesar Rp25 miliar, maka nilai kepemilikan asset per anggotanya adalah Rp26,7 juta.

Koperasi yang juga merupakan kasus koperasi sukses di luar program pemerintah adalah Koperasi Peternakan Bandung Selatan (KPBS) yang berdiri pada tahun 1969, atau di awal Orde Baru. Koperasi ini sebenarnya menggantikan kedudukan dan peranan koperasi peternakan sebelumnya, yaitu Gabungan Petani Peternak Sapi Indonesia Pangalengan (GAPPSIP) yang dibentuk pada tahun 1949. Basis dari koperasi ini adalah peternak sapi perah yang menghasilkan susu, baik susu sebagai bahan susu yang dikonsumsi langsung maupun untuk diolah menjadi produk olahan susu lainnya. Peternak yang berjumlah 6.973 orang itu tersebar di tiga wilayah kecamatan di Bandung Selatan.

Peternakan di Bandung Selatan ini sudah berkembang sejak tahun 180oan, yaitu sebagai usaha swasta Belanda. Pada awalnya, di masa kolonial, produksi susu ditangani oleh empat perusahaan, yaitu De Friesche Terp, Almanak, Van Der Els dan Big Man, dan pemasarannya dilakukan oleh Bandungsche Melk Center. Kesemuanya membentuk sistem agroindustri swasta atau korporasi. Tapi industri ini mengalami kehancuran pada masa pendudukan Jepang, sehingga usaha peternakan susu ini kemudian terpecah ke dalam peternakan-peternakan rakyat individual yang tidak terorganisir. Karena tidak terorganisir, maka sering terjadi kekacauan dalam hal jadwal processing dan pemasaran, sehingga akhirnya merugikan para peternak sendiri. Di masa kemerdekaan, ketika berkembang gerakan koperasi, maka peternakan itu diorganisasikan kembali dalam bentuk koperasi, yaitu GAPPSIP. Tapi koperasi ini mengalami kesulitan ketika berhubungan dengan pemasaran yang dikuasai oleh Industri Pengolah Susu (IPS), dimana IPS menetapkan jadwal pemerahan susu yang tidak sesuai dengan pola kegiatan peternak. Akhirnya pada 1961 koperasi ini bubar, dan 
kembali kegiatan peternakan terserak kepada para peternak hingga kemudian berdiri KPBS.

Berdasarkan kombinasi sistem koperasi modern menurut UU No. 12/1967 tentang Pokok-pokok Perkoperasian dan sistem agribisnis, maka KPBS berperan, pertama, mengintegrasikan kegiatan industri susu dari hulu ke hilir melalui empat tahap, yaitu tahap pra-budidaya, proses budidaya, pemasaran hasil budidaya, dan kegiatan penunjang budidaya yang dilakukan peternak. Integrasi proses agrobisnis itu menghasilkan kualitas standar susu konsumsi maupun susu bahan baku industri. Kedua, dengan dibentuknya unit milk tretment dengan mempergunakan mesin modern yang dimiliki sendiri oleh koperasi, maka produk susu peternak membentuk nilai tambah bagi peternak. Dan ketiga, koperasi menciptakan kekuatan tawar-menawar petani dan bisa menghindarkan diri dari persaingan yang tidak sehat sebagaimana terjadi sebelumnya. Dari segi bisnis, koperasi-koperasi yang telah dibahas di atas bisa disebut sukses. Tapi dalam penilaian ICA, koperasi juga harus memiliki fungsi sosial, yang merupakan bagian dari 7 prinsip koperasi ICA.

Khusus koperasi yang memusatkan perhatian pada tanggung-jawab sosial perusahaan (corporate social responsibility), Koperasi Awak Pesawat Garuda Indonesia (KOAPGI), yang dibentuk pada tahun 2000 oleh 27 orang pramugari Garuda Indonesia, menarik juga untuk diperhatikan. Koperasi ini kini telah berkembang pesat. KOAPGI, melalui kegiatan simpan pinjamnya, mampu memberikan kredit tanpa agunan mulai dari Rp5 juta hingga Rp40o juta. Koperasi ini juga mendirikan mini market dan menyediakan unit perumahan di kawasan Teluk Naga-yang jaraknya masih berdekatan dengan lokasi bandara. Selain itu, untuk mensinergiskan bisnis anggota, KOAPGI juga membentuk Forum Sinergi Bisnis (FORSIBI). Sebagai koperasi serba usaha (KSU), KOAPGI kemudian juga bergerak pada usaha dealer kendaraan dan suplier barang-barang elektronik, serta jasa ticketing kereta api dan pesawat terbang. Dengan jumlah anggota sebanyak 8.664 orang dan nilai aset sebesar Rp93 miliar, maka nilai kepemilikan assetnya sebesar Rp10,7 juta per anggota.

Namun kegiatan yang paling menonjol dari KOAPGI adalah justru kegiatan kemasyarakatan, yaitu pendidikan anak-anak yatim, pembagian sembako gratis, bazar murah, memberi bantuan kepada korban bencana alam, dan melakukan pengembangan masyarakat (community development) di sebuah daerah perkebunan kina di Cilengkrang, Bandung. KOAPGI juga menangani proyek human resource development di PT Garuda Indonesia melalui penyelenggaraan pelatihan-pelatihan. 


\section{PENUTUP}

Dengan demikian, menyimak kembali berbagai kisah sukses koperasi di muka, perkembangan koperasi secara umum mengarah kepada dua pola. Pertama, koperasi menjadi instrumen pengentasan masyarakat dari kemiskinan, yaitu utamanya dengan cara menggerakkan masyarakat untuk melakukan berbagai kegiatan produktif melalui fasilitasi permodalam kredit mikro, sebuah kebutuhan yang tidak mampu dilayani oleh sistem perbankan. Kedua adalah koperasi menjadi wadah pengembangan usaha untuk memperoleh keuntungan. Pada pola kedua, meski koperasi memiliki orientasi bisnis, namun orientasi itu didukung oleh program tanggungjawan sosial koperasi terhadap masyarakat. Pada masa Orde Baru, koperasi sebenarnya di-visi-kan sebagai sokoguru perekonomian desa melalui model koperasi unit desa (KUD). Namun visi yang diwujudkan melalui pembinaan pemerintah ini telah berhenti berkembang pada masa Reformasi.

Akhir abad ke-20, perkembangan koperasi nampak menunjukkan tahap baru. Tahap baru itu bercirikan kenyataan bahwa koperasi justru berkembang di sektor modern. Jika melihat lagi ke belakang, Bung Hatta juga sebenarnya sudah membayangkan bahwa koperasi akan berkembang di lingkungan perusahaan negara dan mengerjakan usaha-usaha skala besar. Bayangan itu ternyata baru terjadi pada akhir abad ke-2o dan kian nampak di permukaan pada awal abad ke-21. Sebagaimana dibayangkan oleh Hatta, koperasi akan mengembangkan individualita yang kreatif, yang pada tahun 2008 tercetus sebagai ekonomi kreatif. Masyarakat koperasi kredit yang terlembaga dalam bentuk CU juga menunjukan bahwa simpan pinjam telah pula mampu mendorong perkembangan ekonomi rakyat yang mampu mengentaskan masyarakat dari kemiskinan.

Gambaran mengenai koperasi sukses dalam 100 Koperasi Besar Indonesia tahun 2011 itu memang menunjukkan bahwa koperasi bisa menjadi badan usaha skala besar yang berkelangsungan. Hanya saja, di sisi lain, perkembangan itu juga memunculkan dilema terkait dengan jati diri koperasi sebagaimana tertuang dalam Statement on the Co-operative Identity yang dimiliki ICA dan menjadi kriteria dalam penyusunan daftar koperasi Global 30o. Kecuali koperasi kredit yang terlembaga dalam bentuk $\mathrm{CU}$, koperasi-koperasi lain yang berorientasi bisnis nampak menimbulkan persoalan. Pertama, koperasi telah menjadi badan usaha yang berorientasi pada investor (investor oriented firm), padahal hakikat koperasi itu adalah melayani pengguna (user oritented firm). Kedua, koperasi telah menjadi perusahaan yang memenuhi kebutuhan masyarakat non-anggota, sedangkan seharusnya koperasi itu memenuhi kebutuhan anggotanya. Ini memang problematis. Jika koperasi hanya memenuhi kebutuhan anggota, yang disebut juga kebutuhan sosial (sociel need), dan tidak merespon kebutuhan pasar (economic need), maka koperasi akan terbatas perkembangannya. Karena itu untuk bisa maju menghadapi tantangan 
ekonomi global, maka koperasi harus berorientasi ke pasar, tetapi tetap memelihara jatidirinya. Ketiga, untuk mengembangkan bisnisnya, koperasikoperasi telah mempergunakan badan usaha perseroan terbatas. Bahkan, struktur kepengurusan koperasi telah diubah menjadi struktur perseroan terbatas, sehingga sekarang ditengarai oleh gerakan koperasi sendiri sebagai proses de-mutualisasi yang dipandang telah menjauhi jati dirinya.

Masalah lain adalah menyangkut visi dan misi koperasi di Indonesia. Pada awalnya visi koperasi adalah menjadi lembaga ekonomi yang bisa mengentaskan masyarakat dari kemiskinan. Namun sekarang visi dan misi koperasi adalah menjadi badan usaha yang bertujuan mencari keuntungan, walaupun untuk anggota. Perubahan arah visi dan misi koperasi itu sebenarnya bertolak dari pertanyaan masyarakat sendiri, yaitu mengapa koperasi berada di buritan perkembangan ekonomi?! Pertanyaan itu kemudian direspon dengan perbaikan manajemen yang mengikuti sistem perseroan terbatas, sehingga lahirlah koperasi-koperasi sukses, terutama jika diukur dengan kriteria bisnis. Namun demikian, koperasi besar tetap membedakan dirinya dari korporasi swasta, karena mereka bekerja dalam koridor jati dirinya sebagai organisasi ekonomi yang berbasis sumber daya manusia sebagai modal sosial.

\section{DAFTAR PUSTAKA}

Danusaputro, Marjanto, dkk. (Editor). 1991. Monetisasi Pedesaan: Bunga Rampai Keuangan Pedesaan. Jakarta: LPPI.

Djohan, Djabaruddin (Editor). 2003. Masih Adakah Hari Depan bagi Koperasi di Indonesia?. Jakarta: LSP2I.

Djohan, Djabaruddin. 1997. Setengah Abad Pasang Surut Gerakan Koperasi Indonesia. Jakarta: Dekopin.

Hatta, Mohammad. 1954. Menindjau Masalah Kooperasi. Djakarta: PT Pembangunan.

Hatta, Mohammad. 1971. Membangun Kooperasi dan Kooperasi Membangun. Djakarta: Pusat Kooperasi Pegawai Negeri Djakarta Raja.

Soedjono, Ibnoe, dkk. 1996. Koperasi di Tengah Arus Liberalisasi Ekonomi. Jakarta: Formasi.

Soedjono, Ibnoe. 2007. Membangun Koperasi Mandiri dalam Koridor Jati Diri. Jakarta: LSP2I-ISC. 